\title{
NDRG2 Gene
}

National Cancer Institute

\section{Source}

National Cancer Institute. NDRG2 Gene. NCI Thesaurus. Code C104084.

This gene is involved in the regulation of cellular differentiation. 